Vol. 3: 49-59, May 2017

ISSN: 2392-4535 (Print), 2392-4543 (Online)

DOI: http://dx.doi.org/10.3126/jnarc.v3i1.17276

\title{
Biotechnology for Conservation and Utilization of Agricultural Plant Genetic Resources in Nepal
}

\author{
Bal Krishna Joshi ${ }^{@}$ \\ National Agriculture Genetic Resources Center (National Genebank), NARC, Khumaltar, PO Box 3055, Kathmandu. @: joshibalak@yahoo.com; \\ http://orcid.org/0000-0002-7848-5824
}

Received June 2016, Revised January 2017, Accepted April 2017, Published May 2017 Scientific Editors: Jiban Shrestha, Umesh Acharya, Tek B. Gurung

Copyright @2017 NARC. Permits unrestricted use, distribution and reproduction in any medium provided the original work is properly cited

\begin{abstract}
Agricultural biodiversity is the basis of human life and food security. Nepal with 577 cultivated species possesses huge diversity at varietal as well as landrace levels. In most agricultural crops the rapid genetic erosion due to several reasons is a common phenomenon. Thus, considering the importance of agricultural biodiversity declared by Convention on Biological Diversity for sustainable food production, National Agriculture Genetic Resources Center (NAGRC) has been established for conservation and sustainable utilization of agricultural biodiversity. This paper thus delineates the application of biotechnological tools adopted by NAGRC for effective and efficient conservation and use of agricultural plant genetic resources (APGRs). Among the adopted technologies, tissue bank using shoot tip culture of vegetatively propagating and recalcitrant crops eg potato, sugarcane, banana, sweet potato, etc are in function. Under the molecular marker technology, currently random amplified polymorphic DNA (RAPD) and simple sequence repeat (SSR) markers have been used for developing DNA profiles, identifying duplicates in the collections, assessing genetic diversity and screening accessions against economic traits. DNA bank has also been created for storing DNA of indigenous crops and these DNA can be accessed for research and study. Genotypic database has been developed for chayote, finger millet, wheat and maize for identification and selection of the accessions.
\end{abstract}

Keywords: Agricultural plant genetic resources, Conservation, DNA bank, Genetic diversity, Molecular profiling, Tissue culture

सारंश

कृषि जैविक विविधता खाध्य र पोषण सुरक्षाको आधार हो । नेपालमा प३७७ प्रजातिका बाली बस्तु हरूको खेति गरिन्छ। ति भित्र पनि अनेक जातीय विविधता रहेको पाईन्छ। तसर्थ, विविध बाली, बस्तुको बिड बिजन सरक्षण र सम्बधर्न खाध्य सुरक्षाका अत्यन्तै महत्वपूर्ण पक्ष हो । कृषि जैविक स्रोतहरु संरक्षण र दिगो सदुपयोगको लागि राष्ट्रिय जिन बैंकको स्थापना भएको छ। उक्त केन्द्रले कृषि अनुबंशिक स्रोतहरुको सरक्षण गर्न जैविक प्रबिधि, तन्तु प्रबिधि र डी.एन.ए. प्रबिधिको प्रयोग गर्द छ। बिउनै उत्पादन नहुने बालि तथा बिड उत्पादन भए पनि बिड धेरै मात्रामा सुकाउन नसकिने बालिहरु जस्तै आलु, उखु, केरा, सखाखण्ड आदिको तन्तु बैंक स्थापना गरि संरक्षणको साथै अनुसन्धान कर्ता र कषकलाई उपलब्ध गराउदै आएको छ। नेपालको बिभिन्न ठाउँवाट यस्ता बाली संकलन गरिएको छ। डी.एन.ए. प्रबिधि अन्तर्गत, आर एपी डी र एस एस र संकेत प्रयोग गरि डी.एन. ए फिंगर प्रिन्ट, एकै थरिको संकलनलाई ब्यबस्था गर्ने, अनिबंशिक विविधता अध्ययन, र आर्थिक दस्टी ले महत्व मानिने बिशेष गुण भएको स्थानीय जातहरु छनौट गर्ने जस्ता कार्य भैरहेको छ। स्थानीय जातहरुको डी.एन.ऐ. बैंक स्थापन गरि डी.एन.ऐ. आदानप्रदान कार्यलाई सहज गरिएको छ। इस्कुस, गहु, मकै र धानको जातीय अनुबंशिक आँकडा ब्यबस्थित गरि संकलन छनौटमा टेवा पुराउदै आएको छ। यी दुवै तन्तु र डी.एन.ऐ. प्रबिधि मार्फते कृषि जैविक विविधतालाई प्रभाकारी डंगले संरक्षण गरिएको छ।

\section{INTRODUCTION}

Agricultural Plant Genetic Resources (APGRs) are the main source of feed to ever growing population. Global food security has been depended on APGRs available across the globe. However, the loss in crop diversity has been estimated to be around 75\% between 1900 and 2000 (FAO 2011). Similarly 16-22\% of wild relatives of different food crops of potato, beans, peanuts are predicted to disappear by 2055 due to effect of climate change alone v (Jarvis et al 2008). Before Convention on Biological Diversity (CBD, http://www.cbd.int/convention/), there was almost free exchange of APGRs among the countries. All countries have sovereign rights to legislate, manage, exploit and control access to their natural resources (CBD 1992). Nepal has been a signatory to the CBD in June 1992 and ratified it in November 1993. The Ministry of Forest and Soil Conservation (MoFSC) is the focal ministry representing Nepal on convention of biological diversity. Restricted access to APGRs may lead to food and nutrition insecurity in the world, therefore, International treaty is evolved to facilitate the availability and utilization to APGR worldwide. 
International treaty on plant genetic resources for food and agriculture ITPGRFA (http://www.planttreaty.org/) is a global treaty for food security and sustainable agriculture. The treaty has been conceptualized and evolved from International Undertaking of Plant Genetic Resource (IUPGR) of the United Nations' Food and Agriculture Organizations (FAO). Nepal ratified ITPGRFA at $2^{\text {nd }}$ January 2007 and became party at $19^{\text {th }}$ October 2009 and Ministry of Agricultural Development (MoAD) is the focal ministry for the Treaty (www.moad.gov.np). The treaty plays the role in conservation and sustainable use of APGRs and the fair and equitable sharing of benefits.

Nepal being the party to CBD and ITPGRFA, it is necessary to manage APGRs available in the country for long term availability to researchers as well as growers and country food security. Rapid genetic erosion has been noticed in most of crops. Therefore, National Gene bank has been established in Nepal. Sustainable management of APGRs requires a multipronged approach and biotechnological tools to contribute on management and sustainable utilization of APGRs. The conservation and utilization of agricultural biodiversity would require modern tools thus; the objective of this paper is to elucidate biotechnological tools for conservation and utilization of agricultural plant genetic resources in Nepal.

\section{AGRICULTURAL BIODIVERSITY AND CONSERVATION INITIATIVES}

Nepal is mountainous agricultural country, where crop cultivation occurred in a wider vertical elevation from $60 \mathrm{~m}$ (in Kechana Kalan, Jhapa where rice is grown) to $4700 \mathrm{~m}$ (in Khumbu, Solukhumbu where potato is grown). Rice is grown at an altitude of $3050 \mathrm{~m}$ in Chhumjul, Jumla, representing the highest elevation of rice growing areas in the world. Probably Khumbu represents the highest potato grown altitude on the earth. In terms of biodiversity richness, Nepal ranks $31^{\text {st }}$ position at global level and $10^{\text {th }}$ position in Asia (GoN/MoFSC 2014). Nepal holds 3.2\% of angiosperm and flora diversity occurred in the world. The rich biodiversity in Nepal is mainly because of prevailing climatic variation ranging from tropical to alpine cold semi desert locations. The agricultural diversity in Nepal is endowed with four main components: plant and crop, animal, aquatic and associated genetic resources. For each component, there are four sub-components represented by domesticated, semi-domesticated, wild edible and wild relative species. In Nepal altogether there are 6973 flowering plant species, 790 food value plant species and 577 cultivated plant species including forage species recorded (Upadhyay and Joshi 2003, Joshi 2017). In Nepal, occurrence of eight agro-ecosystems has been categorized, such as rainfed high hill, rainfed mid hill, rainfed Tarai, irrigated high hill, irrigated mid hill, irrigated Tarai, wetland agriculture and rangeland agriculture. Among 577 cultivated species; 484 species are indigenous and 93 are introduced species including forage species. About 224 wild species are closely relative of cultivated ones. Besides that three broad groups of APGRs categorized are 64 agronomic crops, 145 horticultural crops and 275 forages, respectively.

Human and complex natural factor causes the loss of biodiversity especially the agricultural crop biodiversity over the time. Therefore, visualizing the importance of agricultural biodiversity for sustainable food production for ever increasing population according to the global agenda, the Government of Nepal, Nepal Agricultural Research Council (NARC) has therefore, established the National Agriculture Genetic Resources Center (NAGRC) in 2010. The purpose of the NAGRC is the conservation and preservation of agro-biodiversity, targeting to create a single entry point to get access to genetic resources and its related database. The NAGRC has adapted three conservation strategies, ex-situ, on-farm and in-situ conservation approaches in collaboration with various stakeholders for collection, characterization, evaluation, regeneration, multiplication, pre-breeding, utilization, safety duplication and exploration. Agricultural biodiversity are conserved in Seed Bank, Field Bank, Tissue Bank, DNA Bank and Community Seed Bank. NAGRC has currently more than 11,000 accessions of more than 70 crops (Joshi et al 2013).

\section{CONSERVATION BIOTECHNOLOGY}

APGRs are essential for sustainable utilization so current and future demand of food and nutrition could be accomplished. Scientific discoveries and improvements in biotechnology have created novel opportunities for APGRs conservation and utilization (Joshi and Bimb 2001). In-vitro culture and cryopreservation techniques have made it easy to conserve APGRs, especially those species that are difficult to conserve as seeds.

In modern time for production of virus free plants, technologies of plant tissue culture are widely used. Tools such as Enzyme-linked immune-sorbent assay (ELISA) and polymerase chain reaction (PCR) are used to test viruses and pathogen 
for seed health testing. DNA markers are used for germplasm characterization, diversity and evaluation in order to identify redundancies, test their stability, integrity, and resolve taxonomic relationships. According to Engelmann (2011) in-vitro techniques are useful for conserving plant biodiversity, including (a) genetic resources of recalcitrant seed and vegetative propagated species, (b) rare and endangered plant species and (c) biotechnology products (elite genotypes and genetically engineered material). Explants can be efficiently collected from recalcitrant seed and vegetative propagated species under field conditions using in-vitro techniques. In-vitro culture techniques are useful for production and rapid multiplication of disease-free material. Medium-term conservation is achieved by reducing growth of plant material, thus increasing intervals between subcultures. For long-term conservation, cryopreservation in liquid nitrogen, $-196^{\circ} \mathrm{C}$ allows storing plant material without modification or alteration for extended periods, protected from contaminations and with limited maintenance.

Rao (2004) mentioned that molecular techniques provide several opportunities to conservation and management of APGRs. Result of random amplified polymorphic DNA (RAPD) analysis in 14 phenotypically uniform accessions of Brassica oleracea were reduced to 4 groups with minimal loss of genetic variation (Phippen et al 1997). Molecular markers are being increasingly used for resolving problems related to taxonomy and phylogenetic relationships (Rao and Riley 1994).

\section{BIOTECHNOLOGICAL APPROACHES FOR APGR CONSERVATION AND USE}

In the past, conservation efforts have been mainly focused on orthodox seeds such as rice, maize, wheat, soybean, mustard, chili, etc. Hence conservation methods are well advanced for such crops. There are many other important crops that are sterile or seed is not produce easily or produce recalcitrant seeds such as citrus, banana, mango, sweet potato, sugarcane, cassava, yam, potato and taro, etc. These species are generally conserved in field genebanks, which facilitate easy access to material for use and provides close to natural habitat. But, these crops still might have the risk of loss by different natural calamities, pests and diseases. According to Uyoh et al (2003) and Rao (2004), safety duplicates of these crop species are therefore, needed to establish using alternate strategies of conservation and tissue culture method has contributed significantly by providing paired in-vitro conservation options.

DNA markers are very effective to manage all kinds of APGRs including orthodox, non-orthodox seed and vegetatively propagated crops (Rao 2004). It is not only the conservation which is important but utilization of conserved materials is also important, thus being accelerated through the advances made in biotechnology. NAGRC has utilized in-vitro tissue culture and molecular marker technologies to conserve and utilize APGRs in Nepal.

\section{A. In-vitro tissue conservation}

Orthodox seed can easily be dried and stored at a low temperature for many years. Recalcitrant seeds and vegetatively propagating crops need alternatives for long term conservation. In-vitro tissue conservation has been considered widely and different factors need to be standardized for effective in-vitro culture. This technique is very effective for conserving those crop species, which either produce recalcitrant seeds or does not produce any seeds. Plantlets can be kept in test tubes on nutrient medium for indefinite periods of time by transferring at regular interval. It requires little space for preservation of a large number of crop landraces. Plantlets are maintained in an environment free of pests or pathogens and can easily be kept free from viruses, insect parasites, fungi or bacteria. It also protects against dangers of natural environmental hazards. It offers the availability of nucleus stock to multiply a large number of plants rapidly. It minimizes the obstacles generally imposed by quarantine systems on the movement of live plants. Because of such advantages, in-vitro tissue culture has been initiated in NAGRC with the following objectives: Development of Tissue Bank and Cryo Bank, Conservation of plantlets of vegetatively propagated crop species and species with recalcitrant seeds, through in-vitro (shoot tip) culture in cold storage (medium term conservation), Cryopreservation of vegetatively propagated crop species and species with recalcitrant seeds through shoot tip culture (long term conservation) and Multiplication and distribution of in-vitro cultured plantlets.

In NAGRC, tissue bank of 5 crops (Table 1, Figure 1) using shoot tip explants have been developed and it is being maintained at slow growth condition. The growth of in-vitro culture plantlets can be slowed down during storage through one or a combination of several methods eg by reducing the concentrations of the minerals or by using media with lower salt concentrations ( $\mathrm{Ng}$ and $\mathrm{Ng} \mathrm{1991),} \mathrm{using} \mathrm{low} \mathrm{incubation} \mathrm{temperatures} \mathrm{(Dale} \mathrm{1980,} \mathrm{Ruredzo} \mathrm{and} \mathrm{Hanson} \mathrm{1991),} \mathrm{by} \mathrm{the} \mathrm{addition}$ of osmotica ( $\mathrm{Ng}$ and $\mathrm{Ng} \mathrm{1991,} \mathrm{Ruredzo} \mathrm{and} \mathrm{Hanson} \mathrm{1991),} \mathrm{by} \mathrm{reduction} \mathrm{of} \mathrm{the} \mathrm{gas} \mathrm{pressure} \mathrm{in} \mathrm{culture} \mathrm{vessels} \mathrm{(Bridgen} \mathrm{and}$ Staby 1981) and by varying the light regime (Mullin and Schelegel 1976), etc. 
Depending on crop species, slow growth procedures permit clonal material to be held for 1-15 years under tissue culture conditions with periodic sub-culture (Engelmann 1997). The factors that limit tissue culture have been identified as temperature, light intensity and light duration. Temperatures of $0-5^{\circ} \mathrm{C}$ are used with cold tolerant species, but, temperatures of $15^{\circ}-20^{\circ} \mathrm{C}$ are recommended for tropical species. Growth can also be limited by modifying the culture medium, mainly by sugar reducing and changes concentration mineral elements and by covering explants with a layer of liquid medium or mineral oil for reduction of oxygen level in cultures (Withers and Engelmann 1997).

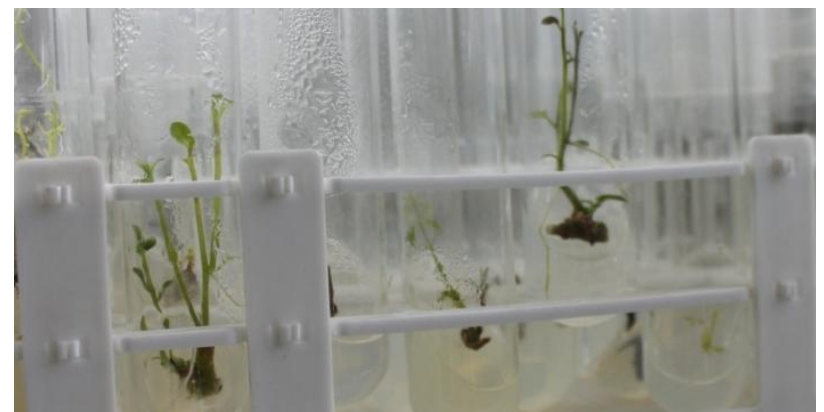

Table 1. Crops and number of accessions conserved in-vitro in NAGREC

\begin{tabular}{lc}
\hline Crop & Number of accessions \\
\hline Potato & 6 \\
Banana & 1 \\
Cardamom & 1 \\
Sugarcane & 2 \\
Sweet potato & 1 \\
\hline
\end{tabular}

Figure 1. Potato accessions maintained in-vitro in NAGRC, Khumaltar.

According to Withers and Engelmann (1997) successful regeneration and propagation of stable seedlings from in-vitro cultures are pre-requisites for any in-vitro conservation and techniques for clonal multiplication are well established for a number of species and slow growth procedures have been developed for a wide range of species; however, they are routinely used only for a few species including banana, potato, sweet potato, cassava, yam, Allium spp and temperate tree species for conservation. Shoots used for slow growth storage since undifferentiated tissues eg callus are source of somaclonal variation.

Generally, shoots are used for slow growth storage since undifferentiated tissues eg callus are more vulnerable to somaclonal variation. Slow growth procedures have been developed for a wide range of species; however, they are routinely used only for a few species including banana, potato, sweet potato, cassava, yam, Allium spp. and temperate tree species for conservation.

\section{B. Molecular markers technology (RAPD and SSR)}

In NAGRC, molecular marker technology has been applied for generating DNA finger printings, analyzing genetic diversity, characterizing germplasms, establishing DNA bank using RAPD and SSR markers. Genotypic database are being linked with other data eg phenotypic data, passport data and use data. This database will be available online at www.genebanknarc.gov.np. These activities have also been carried out in collaboration with different breeding institutes and universities.

DNA finger printing: DNA finger printing of landraces is being considered important ownership document. Such information will be very useful for dispute settlement. NAGRC have focused to develop DNA finger printings of indigenous crops. Currently RAPD and SSR (simple sequence repeat) profiles (Figure 2) of chayote, finger millet, sugarcane, maize, wheat and cardamom have been developed. Following to the methods developed by Thomas et al (1994), markers have been applied for verification of accession identity, DNA fingerprinting and genetic contamination in many genebanks around the globe. For example, SSR was used to differentiate dissimilar cultivars of grapevine. 

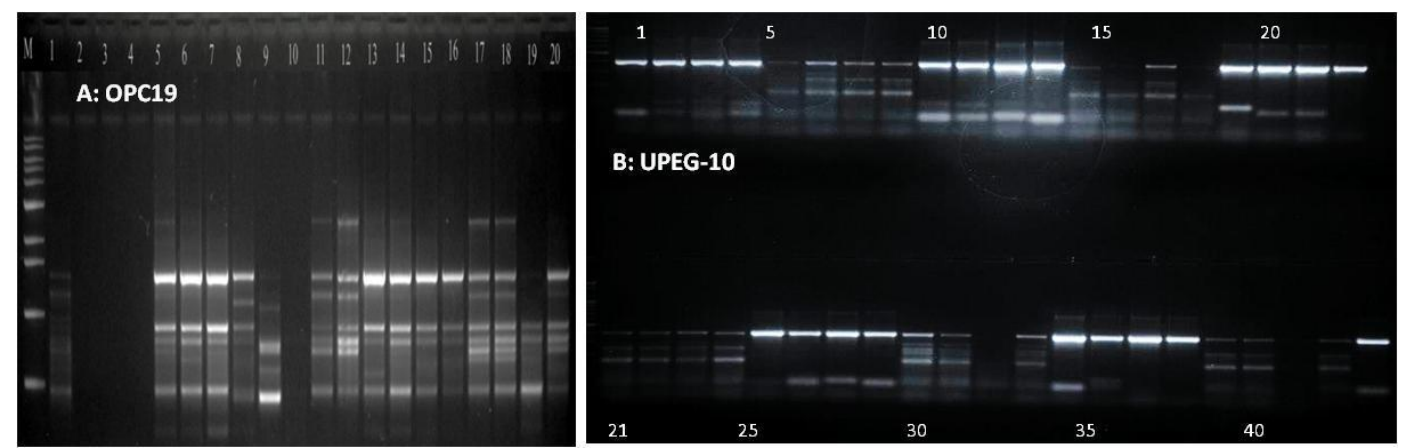

Figure 2. RAPD profiles of 12 chayote accessions (A) and SSR profiles of 40 finger millet accessions.

Genetic diversity analysis: In NAGRC, molecular marker technology has been used to analyze the genetic diversity of genetic resources is being used as a strategy to complement the conventional approaches to evaluation of the effective management and operation are essential. This can be run in using some of the phase of growth excluding the impact of all environments, all of the plant, which requires only a small amount of substances.

After developing DNA profile of germplasm, genetic diversities mainly using multivariate technique were analyzed in chayote, finger millet, cardamom and wheat. This genetic diversity information will be useful for selecting parental lines during hybridization, for managing accessions, for designing sampling strategies, for identification of gaps in the collections, identification of redundancies, identification of genetic contamination, etc. For example, if most of the diversity is within populations and not between populations, priority is given on collecting large numbers of different plants from few populations. NAGRC is also using genetic information generated on a number of crops by different researchers (Joshi and Bimb 2004, Joshi et al 2009, Bajracharya et al 2012).

Screening for a particular traits: Under the pre-breeding program, NAGRC has focused on screening the collections using linked DNA markers with economic traits eg drought tolerance in rice and maize (Figure 3), submergence tolerance in rice, blast resistance in rice, quality protein in maize, rust resistance in wheat (Genebank 2016). Most of these screening works are under the process and is planned to expand to other crops. Molecular screening results will be provided to breeders and will collaborate if necessary for marker assisted selection. It helps in findout of unique genotypes of special importance to genebanks and breeders.

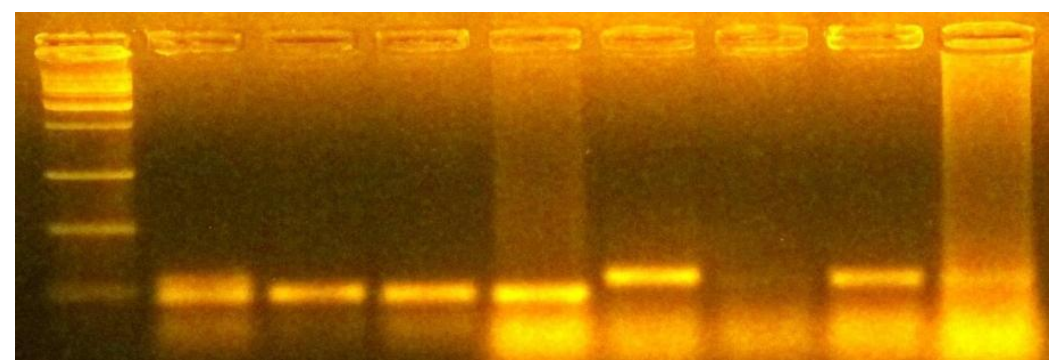

Figure 3. DNA profile of maize accessions using drought resistance marker, BNLG2190.

DNA Bank: According to de Vicente (2006) DNA Bank, as a part of the Genebank is a repository of DNA, usually for research. The DNA Bank is conserving the different kinds of DNA extracted from the genetic resources in tubes at $-40^{\circ} \mathrm{C}$ (Genebank 2016). DNA conserved in DNA Bank is used for studies and research at molecular levels. DNA banking is the secure, long term storage of an individual's genetic material.

Molecular Research Lab in NAGRC, focuses on identification, genetic diversity analysis, and genes and QTLs tagging and mapping. During molecular research, DNA is generally extracted from young growing leaves. The DNA extraction protocol followed by NAGRC is a standard CTAB-chloroform extraction with ethanol precipitation and washing, followed by cleaning with ethidium bromide gradient. After genotyping, remaining DNA is quantified and conserved ex-situ in a Deep Fridge. Further, part of the DNA will be distributed on request for further research and study. DNA Bank was started from 
2013 by conserving the DNA of 12 accessions of chayote in NAGRC, Khumaltar (Table 2) and its database is also maintained.

Table 2. Crops and number of accessions of which DNA are being conserved in DNA bank of National Genebank, Khumaltar

\begin{tabular}{lccc}
\hline Crop & Number of accessions & DNA conc, $\mathbf{n g} / \boldsymbol{\mu l}$ & Volume, $\boldsymbol{\mu l}$ \\
\hline Bean & 75 & 100 & 100 \\
Cardamom & 6 & 100 & 100 \\
Chayote & 12 & 800 & 100 \\
Finger millet & 40 & 100 & 150 \\
Maize & 99 & 200 & 200 \\
Rice & 25 & 50 & 150 \\
Rice bean & 50 & 100 & 100 \\
Sugarcane & 2 & 100 & 150 \\
Wheat & 64 & 300 & 50 \\
\hline
\end{tabular}

The DNA can be used for various applications, for example, characterizing the source material, understand genetic and evolutionary relationships between taxa, functional analysis of genes, comparative genomics and plant breeding (Dean et al 1999, Lund et al 2003, Spooner et al 2005). However, at the moment there is not a technology for raising plants of DNA and DNA databases cannot replace genebanks conventional seeds, repositories in vitro or cryotube banks. Therefore, the DNA database is considered a complementary conservation strategy that along with other conservation strategies leads to an ideal and sustainable use of genetic diversity.

Studies suggest that the purified DNA dissolved in buffer, warehouses and up to $1-2$ years in $4^{\circ} \mathrm{C}, 4-7$ years in $-18^{\circ} \mathrm{C}$ and more than 4 years when stored in $-80^{\circ} \mathrm{C}$ (de Vicente et al 2006). It has been proved that the procedures used to remove debug degrading agents and PCR inhibitors can shear the DNA and also remove the proteins that stabilized the tertiary structure of DNA. The long-term stability of DNA extracted is not fully studied. However, when dry, the DNA extracted shows greater stability.

While DNA extraction is a routine activity of numerous laboratories working in diverse areas of genetics, biochemistry, molecular biology and biotechnology, DNA banking is not widespread. One of the oldest DNA collections is the Frozen Zoo, hosted by the Zoological Society of San Diego, which has preserved the genetic material of approximately 7000 endangered or threatened animal species (mammals, birds and reptiles) in the form of frozen tissue samples for the extraction of DNA for its subsequent use in conservation research (de Vicente et al 2006). A recent worldwide survey by International Plant Genetic Resources Institute revealed that of the 274 respondents from 77 countries, 51 (21\%) stored DNA while the rest did not. Some of the major plant DNA banks are Australian Plant DNA Bank, Lismore, Australia; DNA bank, Instituo de Pesquisas, Jardim Botanico de Rio deJaneiro, Brazil; Missouri Botanical Garden, Missouri, USA; Royal Botanic Gardens, Kew, Great Britain, National Institute of Agrobiological Sciences (NIAS), Ibaraki, Japan (de Vicente et al 2006).

Another potential area of DNA bank is exchange of genetic resources. It will be a lot easier to exchange genetic resources as DNA samples, rather than seed or vegetative propagules. Trans-boundary movement of seed and other planting material requires time consuming inspection and phyto-sanitory certification for freedom from pests and diseases. Exchanging DNA samples, on the other hand, avoids the need for time consuming and costly certification procedures.

Genotypic database: Database of each accession conserved in the Genebank has been maintained at NAGRC. Further, all kinds of databases, for example passport, characterization and evaluation, stock management, phenotypic and genotypic have been maintained. After genotypic study, all kinds of genotypic data are being maintained.

\section{POTENTIAL APPLICATION}

Currently NAGRC has limited application of biotechnology for APGR conservation and utilization. This is due to limited human resources, expertise and financial support. However, following areas under in-vitro tissue conservation and molecular marker technology has been explored as potential application of biotechnology for better managing APGR in the country. 


\section{A. In-vitro tissue conservation}

There are many success cases of in-vitro tissue culture applied for conservation of APGRs in the world (Dale 1980, Engelmann 1997) with many literatures and guidance on propagation of rare plants, including techniques for large-scale propagation, storage and reintroduction. The in-vitro techniques for conserving plant biodiversity include shoot apical or axillary-meristem-based micro-propagation, somatic embryogenesis, cell culture technologies and embryo rescue techniques, as well as a range of in-vitro cold storage and cryopreservation (Engelmann 1997, Reed et al 2011), in-vitro collection, pathogen free plantlet maintenance and efficient germplasms exchange.

Cryopreservation: NAGRC has only medium term storage for recalcitrant seed crops and vegetative propagated crops showing tissue bank in slowly emerging up. For the long term storage of these crops, cryo-bank is necessary to establish in the future. The principle of cryopreservation is storing plant material in liquid nitrogen $\left(-196^{\circ} \mathrm{C}\right)$ at this temperature and the material can be stored for long periods of time due completely arrested of cell division and metabolic activities. Cryopreservation is the only available method for long-term conservation of vegetative propagated crops (Engelmann 2004, Chauhan 2016). In NAGRC there is need to develop the facilities to preserve the animal and aquatic tissues for their subsequent use in conservation research. However, some preliminary research works on preservation of semen in liquid nitrogen containers has been initiated under the Animal Breeding Research of National Animal Science Research Institute in NARC.

In-vitro collection: In-vitro technology provides solutions to secure seeds damage caused by insects, animals and birds or diseases to, big and fleshy seeds such as coconut, which are not likely to remain viable during transport (Pence et al 2002, Withers 1995). Now there are techniques allowing the collection of small zygotic embryo from fields and transfer them in sterile conditions for genes to grow them on a medium-culture (Ashburner et al 1996). There are many tropical and subtropical tree species which produce recalcitrant seeds and do not survive desiccation, for which conventional seed storage strategies are not possible and need to consider in-vitro technique for collections (Roberts 1973).

Pathogen free plants production: Healthy germplasm with the ability of storing long term is the fundamental for effective conservation and utilization APGRs (Brown et al 1988, Engelmann 1997, Hasan and Tagaki 1995). Infected propagules deteriorate quickly in storage conditions; therefore it is important to store only healthy samples in the genebanks. In-vitro tissue culture technique through meristem tip has potential to produce pathogen free plants. Thermotherapy and meristem-tip culture are most widely used for production of virus free collections in the in-vitro genebank at the International Center for Tropical Agriculture (CIAT) (IPGRI/CIAT 1994). Other successful elimination of viruses from important crop species are cassava mosaic virus from cassava (Kartha and Gamborg 1975), exocortis viroid from Citrus species (Greno et al 1990), potato virus S from potato (Brown et al 1988) and sweet potato yellow dwarf virus from sweet potato plants (Green and Lo 1989).

Germplasms exchange and use: Exchanging germplasm developed across cultures in-vitro tissue provides many advantages to low volume and weight beyond the pathogenic plantlets free. Using shoot tips of bananas encapsulated in alginate beads (Rao et al 1993) and encapsulated nodal segments in yam and potatoes (Hasan and Takagi 1995) have been suggested as an alternative to the germplasm exchange. For these sterile conditions is maintained and simplify the process of regeneration.

\section{B. Molecular markers technology}

New methods and tools have been rapidly developing in molecular marker technology. This offers wide range of application for effectively and efficiently managing the agricultural biodiversity (Spooner et al 2005). Nepal should also consider molecular marker technology for duplicates management, determining the sampling strategies, genetic integrity and monitoring study and for seed health testing.

Duplicates management: It is very common to have duplicates in the collections. This increases the cost of maintenance and may not be able to capture other diversity. Phenotypically it is not possible to manage the duplicates (Dean et al 1999). Therefore, many genebanks around the globe has applied molecular marker technology for identifying duplicates. For example, amplified fragment length polymorphism (AFLP) marker has been used to reveal intra accession variation in ex-situ conserved barley. The findings were applied for splitting heterogeneous accessions into distinct lines in order to avoid the negative effects of selection and genetic drift during regeneration (van Treuren and van Hintum 2001). Other examples are RAPD in wheat (Cao et al 1998), SSR in sorghum (Dean et al 1999), SSR in barley (Lund et al 2003), AFLP in wild bean (Tohme et al 1996). 
Use for sampling strategies (collection sites, populations or in-situ sites): Information at genetic level is very useful for designing sampling strategies (Ghislain et al 1999). Genetic diversity if one could relate to geography can be used to determine the collection sites, sample sizes as well as for in-situ or on-farm conservation. Diversity at intra or inter landraces is useful for sampling strategies. Intra-species diversity has been explored for geographic or ecological patterns of diversity distribution in many crop species and their wild relatives that include wild bean (Tohme et al 1996), banana (Pillay et al 2001), mango (Kashkush et al 2001), bambara groundnut (Massawe et al 2002), vetch (Potokina et al 2002).

Genetic integrity and monitoring: After the conservation over the years, it is important to study its genetic integrity and needs regular monitoring. DNA markers offer a great advantage for such kind of study in the Genebank. RAPDs had been used to study the changes in genetic diversity following regeneration of potato, rapeseed and wheat accessions (Del Rio et al 1997, Wu et al 1998, Borner et al 2000).

Seed health testing (disease diagnosis): During germplam exchange as well as collections, there is increasing risk of introduction or collection of pathogens. Diseases in crops, caused by viruses, bacteria, fungi and nematodes, threaten food security in resource-poor countries and cause heavy damage and economic loss every year (Vurro et al 2010). Early and accurate detection and diagnosis of plant pathogens is indispensable for minimizing the risk posed by pathogens during research and production. Detection of pathogen is also of paramount importance in germplasm collections to enable the storage and exchange of healthy germplasm. Biotechnological diagnostic tools, such as ELISA and PCR-based methods, for pathogen identification can bypass many shortcomings related to culture-based morphological approaches (Chauhan 2016). Vegetative propagates act as source of efficient mean of virus and viroid transmission therefore, pathogen problems are more severe for vegetatively propagated crops. Watermelon PCR used for identifying bacterial fruit blotch pathogen which is as an alternative to grow-out test (Minsavage et al 1995).

Many plant disease diagnostic networks have been established to address issues related to disease diagnosis and pathogen detection, in particular the gap in capacity between developed and developing countries (Miller et al 2009). For example, the Global Plant Clinic has a network of 81 clinics in ten countries across Africa, Asia and Latin America (Boa 2010). It links stakeholders like diagnostic laboratories and researchers with clinics, and also runs a global diagnostic service in the United Kingdom for further testing to identify new diseases (Wilson 2010). It should be initiated to use PCR technique in disease diagnosis in Nepal and build the linkage with such networks.

Accelerating the utilization of germplasm: NAGRC has more than 11,000 accessions of different crops conserved in Seed Bank, Tissue Bank, Field Genebank and DNA Bank (Genebank 2016). Most of them could not be used directly either for breeding or production. If we could identify or develop elite lines, it will accelerate the breeding program. Accessions with important traits (allele and QTL) need to be explored and identified (Rosyara and Joshi 2012). Therefore, molecular marker technology should be extensively applied to identify the accessions with important traits. High throughput genotyping of germplasms allows for the examination of genetic relationships that will be useful for selecting parental lines during crossing and for developing conservation strategy.

\section{Conclusion}

Conventional conservation methods should be complemented with biotechnology for effective and efficient conservation and utilization of APGRs. Biotechnology, particularly in-vitro tissue culture and molecular marker technologies, has contributed substantially to better conservation and usage of APGRs in Nepal. The advancement in in-vitro tissue culture technology has facilitated conserving many accessions of recalcitrant seed crops and vegetative propagated crops in small areas with minimum risks. Three major areas under the principle of tissue culture are in-vitro collecting, slow growth (medium term conservation) and cryopreservation (long term conservation). Tissue bank considering slow-growth technique has been established for potato, banana, sweet potato, sugarcane and cardamom. Molecular marker technology has facilitated on understanding diversity, identification of redundancies in collections, diseases diagnosis, testing accession stability and integrity, supporting the development of effective management strategies for ex-situ, in-situ and on-farm conservation, and in accelerating the utilization, developing finger prints and establishing DNA bank. It has been used for advancing the conservation and use of maize, wheat, rice bean, rice, finger millet, cardamom and sugarcane. In future, NAGRC might 
require to develop and adopt more efficient ways to conserve the agricultural biodiversity for fulfilling food and nutrition security in line with declaration of CBD.

\section{ACKNOWLEDGEMENT}

Financial support was from NARC, Nepal and AFACI, Korea to establish and function two labs (in-vitro culture lab and molecular research lab) for better management of APGR.

\section{REFERENCES}

Ashburner GR, MG Faure and DR Tomilson. 1996. Collection of coconut (Cocos nucifera) embryos from remote locations. Seed Sci. Technol. 24:159-171.

Bajracharya J, AHD Brown, BK Joshi, D Panday, BK Baniya, BR Sthapit and DI Jarvis. 2012. Traditional seed management and genetic diversity in barley varieties in high-hill agro-ecosystems of Nepal. Genet. Resources Crop Evol. 59:389-398. DOI 10.1007/s10722-011-9689-2.

Boa E. 2010. Plant healthcare for poor farmers around the world: Gathering demand and innovative responses. In: Knowledge and Technology Transfer for Plant Pathology, Plant Pathology in the $21^{\text {st }}$ Century 4 (NV Hardwick and ML Gullino, ed), pp.1-16.

Borner A, S Chebotar and V Korzun. 2000. Molecular characterization of the genetic integrity of wheat (Triticum aestivum L.) germplasms after long-term maintenance. Theor. Appl. Genet. 100:494-497.

Bridgen MP and GL Staby. 1981. Low pressure and low oxygen storage of Nicotiana tabacum and Chrysanthemum folium tissue cultures. Plant Sci. Lett. 22:177-186.

Brown CR, S Kwiatkowski, MW Martin and PE Thomas. 1988. Eradication of PVS from potato clones through excision of meristems from in-vitro, heat treated shoot tips. Am. Potato J. 32:558.

Cao WG, P Hucl, G Scoles and RN Chibbar. 1998. Genetic diversity within spelta and macha wheats based on RAPD analysis. Euphytica 104:181-189.

Chauhan RS. 2016. Biotechnological approaches for conservation of rare, endangered and threatened plants. International Journal of Scientific and Research Publications 6(12: 10-14.

Dale PJ. 1980. A method for in-vitro storage of in-vivo apple shoots. Hort. Science 14:514.

de Vicente MC, ed. 2006. DNA banks: Providing novel options for genebanks? International Plant Genetic Resources, Rome.

de Vicente MC, Anderson MS, editors. 2006. DNA banks-providing novel options for genebanks? Topical Reviews in Agricultural Biodiversity. International Plant Genetic Resources Institute, Rome, Italy.

Dean RE, JA Dahlberg, MS Hopkins, SE Mitchell and S Kresovich. 1999. Genetic redundancy and diversity among 'orange' accessions in the US National Sorghum Collection as assessed with simple sequence repeat (SSR) markers. Crop Sci. 39:1215-1221.

Del Rio AH, JB Bamberg and Z Huaman. 1997. Assessing changes in genetic diversity of potato genebanks. 1. Effects of seed increase. Theor. Appl. Genet. 95:191-198.

Engelmann F. 1997. In-vitro conservation methods. In: Biotechnology and Plant Genetic Resources: Conservation and Use (BV Ford-Lloyd, HJ Newbury and JA Callow, eds). CABI, UK, pp119-162.

Engelmann F. 2004. Plant cryopreservation: Progress and prospects. In Vitro Cell. Dev. Biol. Plant 40: 427-433. doi:10.1079/IVP2004541

Engelmann F. 2011. Use of biotechnologies for the conservation of plant biodiversity. In-Vitro Cellular and Developmental Biology 47:516.

FAO. 2011. Current status and options for livestock biotechnologies in developing countries. In: Biotechnologies for agricultural development: Proceedings of the FAO international technical conference on agricultural biotechnologies in developing countries: Options and opportunities in crops, forestry, livestock, fisheries and agro-industry to face the challenges of food insecurity and climate change (ABDC-10).

Genebank. 2016. Annual Report 2072/73 (2015/16). National Agriculture Genetic Resources Centre, NARC (BK Joshi, KH Ghimire, D Singh and S Shrestha, eds). Khumaltar, Lalitpur, Nepal.

Ghislain M, D Zhang, D Fajardo, Z Huaman and RJ Hijmans. 1999. Marker-assisted sampling of the cultivated Andean potato Solanum phureja collection using RAPD markers. Genet. Resour. Crop Evol. 46:547-555.

GoN/MoFSC. 2014. Nepal biodiversity strategy and action plan 2014-2020. Government of Nepal, Ministry of Forests and Soil Conservation, Kathmandu, Nepal

Green SK and CY Lo. 1989. Elimination of sweet potato yellow dwarf virus (SPYDV) by meristem tip culture and by heat treatment. J. Plant Dis. Prot. 96:464-469.

Greno V, M Cambra, L Navarro and N Duran-Vila. 1990. Effect of antiviral chemicals on the development and virus content of citrus buds cultures in-vitro. Sci. Hort. 45:75-87.

Hasan SMZ and H Takagi. 1995. Alginate-coated nodal segments of yam (Dioscoria pp.) for germplasm exchange and distribution. Plant Genet. Resour. Newsl. 103:32-35.

IPGRI/CIAT. 1994. Establishment and operation of a pilot in-vitro active genebank. Report of a IPGRI/CIAT Collaborative Project using Cassava (Manihot esculanta Crantz) as a model. IPGRI, Rome. 
Jarvis A, A Lane and RJ Hijmans. 2008. The effect of climate change on crop wild relatives. Agriculture, Ecosystems and Environment 126:13-23.

Joshi BK and HP Bimb. 2001. Prospects and possibilities of buckwheat development through biotechnology. In: Res. and Dev. on Buckwheat: An Important yet a Neglected Crop in Nepal (HP Bimb and BK Joshi, eds). Proceedings of National Workshop on 1314 Sept 2001, Kathmandu, pp. 83-94.

Joshi BK and HP Bimb. 2004. Classification of Nepalese rice cultivars based on isozymes. In: Rice Research in Nepal (AK Gautam AK, T Akhtar, B Chaudhary, J Gaire and KR Bhatta, eds). Proc. of $24^{\text {th }}$ Summer Crops Workshop 28-30 June 2004 NARC, Khumaltar, pp.175-187.

Joshi BK, D Singh and MR Bhatta. 2013. Genebank manages agricultural plant genetic resources through five different banks. NARC Newsletter 20(3):4-5

Joshi BK, HP Bimb and MP Upadhyay. 2009. Status and prospects of agricultural biotechnology for crop improvement and management in Biotechnology Unit-NARC. In: Proc. National Seminar on Present Status and Future Prospects of Biotechnology in Nepal, 14-15 March 2007, Khumaltar. NAST and MOEST, Kathmandu, pp.21-36.

Joshi BK. 2017. How conservation and utilization of agro-biodiversity advanced from 1937 to 2017 in Nepal. AICC (Golden Jubilee Souvenir) (in press).

Kartha KK and OL Gamborg. 1975. Elimination of cassava mosaic disease by meristem culture. Phytopathology 65:826-828.

Kashkush K, F Jinggui, E Tomer, J Hillel and U Lavi. 2001. Cultivar identification and genetic map of mango (Mangifera indica). Euphytica 122:129-136.

Lund B, R Ortiz, IM Skovgaard and R Waugh. 2003. Analysis of potential duplicates in barley gene bank collections using re-sampling of microsatellite data. Theor. Appl. Genet. 106:1129-1138.

Massawe FJ, M Dickinson, JA Roberts and SN AzamAli. 2002. Genetic diversity in bambara groundnut (Vigna subterranean L. Verdc) landraces revealed by AFLP markers. Genome 45:1175-1180.

Miller SA, FD Beed and CL Harmon. 2009. Plant disease diagnostic capabilities and networks. Annual Review of Phytopathology 47: 15-38.

Minsavage GV, RJ Hoover, TA Kucharek and RE Stall. 1995. Detection of the water melon fruit blotch pathogen on seeds with the polymerase chain reaction. Phytopathology 85:1162.

Mullin RH and DE Schlegel. 1976. Cold storage maintenance of strawberry meristem plantlets. Hort. Sci. 11:100-101.

Ng SYC and NQ Ng. 1991. Reduced growth storage of germplasm. In: In-vitro Methods for Conservation of Plant Genetic Resources (JH Dodds, ed), Chapman and Hall, London.

Pence VC, JA Sandoval, VM Villalobos and F Engelmann (eds). 2002. In-vitro collecting techniques for germplasms conservation. IPGRI Technical Bulletin No. 7. International Plant Genetic Resources, Rome.

Pillay M, E Ogundiwin, DC Nwakanma, G Ude and A Tenkouano. 2001. Analysis of genetic diversity and relationships in East African banana germplasm. Theor. Appl. Genet. 102:965-970.

Phippen WB, S Kresovich, FG Candelas and JR McFerson. 1997. Molecular characterization can quantify and partition variation among genebank holdings: A case study with phenotypically similar accessions of Brassica oleracea var. capitata L. (cabbage) 'Golden Acre'. Theor Appl Genet 94: 227-234.

Potokina E, F Blattner, T Alexandrova and K Bachmann. 2002. AFLP diversity in common vetch (Vicia sativa L.) on the world scale. Theor. Appl. Genet. 105:58-67.

Rao RV and R Riley. 1994. The use of biotechnology for conservation and utilization of plant genetic resources. Plant Genet. Resour. Newsl. 97:3-20.

Rao NK. 2004. Plant genetic resources: Advancing conservation and use through biotechnology. African J. Biotech. 3:136-145.

Rao PS, TR Ganapathi, P Suprasanna and VA Bapat. 1993. Encapsulated shoot tips of banana: A new propagation and delivery systems. Info Musa 2:4-5.

Reed BM, V Sarasan M Kane, E Bunn and VC Pence. 2011. Biodiversity conservation and conservation biotechnology tools. In-Vitro Cell. Dev. Biol. Plant 47:1-4.

Roberts EH. 1973. Predicting the viability of seeds. Seed Sci. Technol. 1:499-514.

Rosyara UR and BK Joshi. 2012. Association mapping for improvement of quantitative traits in plant breeding populations. Nepal Journal of Biotechnology 2:72-89.

Ruredzo TJ and J Hanson. 1991. In-vitro conservation. In: Crop Genetic Resources of Africa (F Attere, E Zedan, NQ Ng and P Perrino, eds). Vol. 1, Trinity Press, UK.

Spooner D, R van Treuren and MC de Vicente. 2005. Molecular markers for genebank management. IPGRI Technical Bulletin No. 10. International Plant Genetic Resources, Rome.

Thomas MR, P Cain and NS Scott. 1994. DNA typing of grapevines: A universal methodology and database for describing cultivars and evaluating genetic relatedness. Plant Mol. Biol. 25:939-949.

Tohme J, DO Gonzalez, S Beebe and MC Duque. 1996. AFLP analysis of gene pools of a wild bean core collection. Crop Sci. 36: 375-1384.

Upadhyay MP and BK Joshi. 2003. Plant Genetic Resources in SAARC Countries: Their Conservation and Management: Nepal Chapter. SAARC Agriculture Information Center, pp.297-422.

Uyoh EA, AE Nkang and EE Eneobong. 2003. Biotechnology, genetic conservation and sustainable use of bioresources. African Journal of Biotechnology 2(12):704-709. 
van Treuren R and ThJL van Hintum. 2001. Identification of intra-accession genetic diversity in selfing crops using AFLP markers: Implications for collection management. Genet. Resour. Crop Evol. 48:287-295.

Vurro M, B Bonciani B and G Vannacci. 2010. Emerging infectious diseases of crop plants in developing countries: Impact on agriculture and socio-economic consequences. Food Sec. 2:113-132.

Wilson S. 2010. Plant doctors: A global prescription for plant pests. Issues 90:34-37.

Withers LA and F Engelmann. 1997. In-vitro conservation of plant genetic resources. In: Biotechnology in Agriculture (A Altman, ed). Marcel Dekker Inc. New York, pp.57-88.

Withers LA. 1995. Collecting in-vitro for genetic resources conservation. In: Collecting Plant Genetic Diversity (L Guarino, V Ramanatha Rao and R Reid, eds). Technical Guidelines. CABI, Wallingford, UK, pp.51-526.

Wu XM, NF Wu, XZ Qian, RG Li, FH Huang and L Zhu. 1998. Phenotypic and genotypic changes in rapeseed after 18 years of storage and regeneration. Seed Sci. Res. 8:55-64. 